\title{
Shedding light on the invisible: addressing the potential for groundwater contamination by plastic microfibers
}

\author{
Viviana $\mathrm{Re}^{1,2}$
}

Received: 24 December 2018 / Accepted: 3 June 2019 / Published online: 29 June 2019

(C) The Author(s) 2019

\begin{abstract}
The processes of microplastic fiber pollution in groundwater are unknown. The recent research on this contaminant threat is generally focused on surface waters (mainly oceans and rivers), while aquifer contamination is only marginally mentioned as an issue needing further investigation. Synthetic microfibers can be introduced into soils in different ways (e.g. wastewater treatment plants or greywater discharge, septic tank outflows, direct injection of contaminated water in cases of managed aquifer recharge, losing streams, etc.), and can thus reach aquifer systems due to leaching or infiltration in soil pores. Microfibers can then adsorb persistent bioaccumulative and toxic chemicals, which include persistent organic pollutants and metals, and become a carrier of harmful substances in the aquifer system, hence contributing to the overall contamination in both urban and rural areas. For this reason, it is of paramount importance, not only to assess the occurrence and fate of microplastic fibers in groundwater, but also to study the role of microplastics as carriers of contaminants within the aquifer and to advance standardization and organization of monitoring campaigns. Only by addressing these key challenges can hydrogeologists contribute to the state of the art on microplastic pollution and ensure that groundwater is not neglected in the environmental assessments tackling this contaminant of emerging concern.
\end{abstract}

Keywords Emerging pollutants $\cdot$ Microplastic $\cdot$ Groundwater monitoring $\cdot$ Water-resources conservation $\cdot$ Contamination

\section{Introduction}

It is the age of plastics and the debate over microplastics pollution has never been more relevant, however a full understanding of its impacts on the natural environment is still far from being reached. Plastic is ubiquitous and, most importantly, everlasting, as practically no biological organism in the Earth's ecosystem has sufficiently evolved to readily consume it (Crawford and Quinn 2017). This implies that everyone has to deal with the side effects of plastic wastes released and accumulating in the natural environment over time (Barnes et al. 2009; UNEP and GRID-Arendal 2016). A recent study (Geyer et al. 2017) estimated that up to $2017,8,300$

Viviana Re

viviana.re@unipi.it

1 Department of Earth and Environmental Sciences, University of Pavia, Via Ferrata 1, 27100 Pavia, Italy

2 Present address: Department of Earth Sciences, University of Pisa, Via S. Maria 53, 56126 Pisa, Italy million metric tons (Mt) of virgin plastics have been produced, and that of the approximately 6,300 Mt of plastic waste generated before 2015 , only a very small percentage had been recycled or incinerated ( 9 and 12\% respectively), while $79 \%$ had accumulated in landfills or the natural environment. The same study affirms that if current production and waste management trends continue, by 2050 , about $12,000 \mathrm{Mt}$ of plastic waste will be in landfills or in the environment. Together with these forms of plastic, which are mainly packaging, bottles and singleuse plastic items, another issue of increasing concern is microplastics, which are defined as plastic particles smaller than $5 \mathrm{~mm}$ in length (Arthur et al. 2008). Microplastics are generally divided into two major categories: (1) primary microplastics intentionally manufactured for use in cosmetics, personal care products, industrial processing (e.g. sandblasting), textile applications, synthetic clothes production, domestic and industrial washing processes of fabrics (Gregory 1996; Fendall and Sewell 2009; Browne et al. 2011) that, being too small to be filtered by waste water treatment plants (WWTPs), can be introduced directly into oceans through direct runoff; and (2) secondary 
microplastics, as those typically generated by degradation and fragmentation of larger pieces of plastics (due to the exposure to ultraviolet light from the sun and/or by mechanical means such as tidal waves; Gregory and Andrady 2003), hence the ones referred to when talking about marine litter (Avio et al. 2016).

First reported in the 1970s in the Sargasso Sea in the North Atlantic (Carpenter and Smith 1972), microplastics have since then been found in several beach sediments worldwide (e.g. Thompson et al. 2004; Costa et al. 2010; Browne et al. 2011; Van Cauwenberghe et al. 2013; Nor and Obbard 2014). Therefore, their abundance in the marine environment, and associated increasing interest from both the scientific community and civil society, has meant that microplastics are gradually passing from being considered a contaminant of emerging concern to being recognized as an emerged threat (Avio et al. 2016). However, it is only recently that the impact of primary microplastics, and microfibers in particular, has started to be acknowledged (Browne et al. 2011). Given that a recent investigation (Tyree and Morrison 2017) estimated that $1 \mathrm{Mt}$ of microplastic fibers are discharged into wastewater each year, where more than half evade treatment and escape into the environment, it is clear that microplastics are an issue that cannot be underestimated and require a strong engagement from the scientific community to avoid further negative consequences due to the lack of knowledge and of complete systematic research.

As the study of microplastics is a relatively new area of investigation, several challenging open questions still need to be addressed (Eerkes-Medrano et al. 2015; Geissen et al. 2015; Avio et al. 2016; Henry et al. 2019), including: (1) assessing microplastics occurrence and distribution in the natural environment, and, particularly in groundwater (as most of the studies focus on seawater, and only recently on surface waters); (2) understanding their transport pathways and factors that affect their distribution; (3) defining the methods for their accurate detection and quantification, including specifics on measurements and the standardization of analytical procedures; and (4) evaluating the extent and relevance of their impacts on both aquatic life and human health.

As a result, a full comprehension of the impact of primary microplastics on the natural environment is still far from being reached and, with regard to freshwater resources, research is in its early stages, while a coordinated monitoring of surface water and groundwater is not yet achieved, but urgently required (Geissen et al. 2015). The invisibility of groundwater makes it difficult to understand, study and manage, and often, as in the case of emerging pollutants, research only develops when the contamination issue has already occurred. It is under these premises, that this review article aims at contributing to highlight the gaps and challenges to be addressed on microplastics contamination in groundwater resources, with a special focus on synthetic microfibers.

\section{Microfibers: an invisible threat}

Fibers are defined as natural or synthetic substances that are significantly longer than wide, and that are often used in the manufacture of other materials (Harper 2017). Apart from asbestos, most of the natural fibers commonly employed in industrial applications are considered to be of no danger to human health (WHO 1986; Fig. 1), although the increasing concern about the biological and environmental impacts of synthetic fibers is driving new research addressing their ecotoxicological effects (Crawford and Quinn 2017, and references therein; Tyree and Morrison 2017).

As regards natural fibers, asbestos is probably the most studied, due to its natural abundance and toxicity. Asbestos is the generic designation for a group of naturally occurring minerals that are formed of thin fibers: chrysotile (the most commonly used form), actinolite, amosite, anthophyllite, crocidolite and tremolite (Strunz 2001). Consisting of separable fibers that are heat-resistant, strong and flexible enough to be spun and woven, these minerals have been widely used in buildings (e.g. fireproofing, acoustic and thermal insulation), automotive parts, tiles, cement and textiles (e.g. special cloths and garments which are resistant to heat and corrosive elements). Even though nowadays the carcinogenic effect of long-term exposure to, and associated inhalation of, asbestos is widely recognized (and mainly attributed to fiber dimensions; International Agency for Research on Cancer 1977; WHO 1986; Madl et al. 2010), some items are still widely debated in the scientific community. For example, based on the World Health Organization definition (WHO 2000), the current regulations only focus on long asbestos fibers (LAF: length: $L \geq 5 \mu \mathrm{m}$, diameter: $D<3 \mu \mathrm{m}$ and $L / D$ ratio $>3$ ), while short asbestos fibers (SAF: length $(L<5 \mu \mathrm{m}$;) are still not taken into account (Boulanger et al. 2014). In addition, since most of the research focuses on airborne asbestos, another open concern is the clear assessment of the health effects of the direct ingestion of asbestos in drinking-water (e.g. Polissar et al. 1983; Di Ciaula and Gennaro 2016), as proven by its absence in drinking-water guidelines (WHO 2013).

Synthetic microfibers are defined as a type of plastic, made up of various synthetic polymers (e.g. polyester, acrylic and nylon fibers), fibrous in shape, and smaller than $1 \mathrm{~mm}$ to $1 \mu \mathrm{m}$ in length (Crawford and Quinn 2017; Fig. 2a). Recent studies have highlighted a significant increase in the production of synthetic fibers to supply the growing demand of the clothing and cleaning products sectors (Qin 2014; Fig. 2b), with polyester alone accounting for over $40 \mathrm{Mt} /$ year (Aizenshtein 2015), and it has been proven that synthetic textiles can shed numerous microfibers during conventional washing (Hartline et al. 2016).

The scope of this problem is evidenced by the growing attention of the productive sector itself, as in the case of 


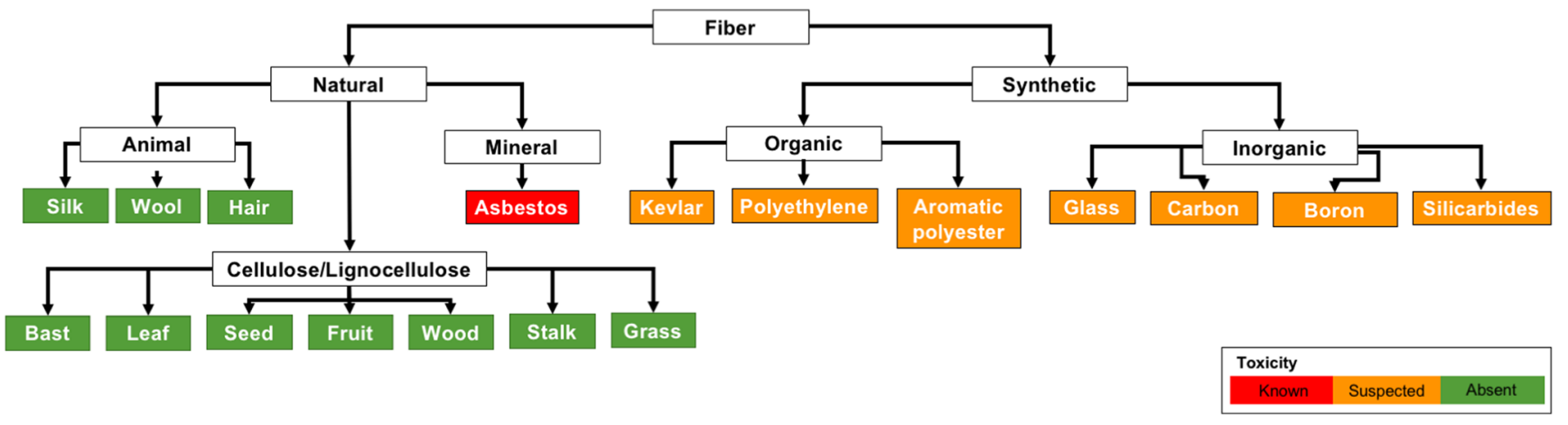

Fig. 1 Classification of natural and synthetic fibers. Modified from Jawaid and Khalil (2011) highlighting in red the fibers with acknowledged toxicity, in green those with no risk, and in orange the fibers with suspected (or still under investigation) toxicity

Patagonia, a company selling outdoor clothing marketed as sustainable, which recently commissioned the University of California (USA) to assess the amount of microfibers released from outerwear during washing. Using the company's sale numbers, the researchers (Bruce et al. 2017) extrapolated that about 100,000 jackets are in use worldwide each year, and washing them would produce enough plastic to make 11,900 grocery bags. When released into the natural environment, being too small to be filtered in WWTPs, the microfibers can end up in seas and oceans, thus contributing to marine litter (e.g. Mintenig et al. 2017; Henry et al. 2019; Magni et al. 2019). In particular, it has been estimated that these tiny fibers make up $85 \%$ of human debris on shorelines across the globe (Browne et al. 2011), and were also recently found in seawater and in fish caught worldwide (e.g. Rochman et al. 2015; Barrows et al. 2018; Gago et al. 2018 and references therein), in table salt (Yang et al. 2015), in beer (Liebezeit and Liebezeit 2014; Kosuth et al. 2018), and even in drinking water (Eerkes-Medrano et al. 2018; Tyree and Morrison 2018; Schymanski et al. 2018; Koelmans et al. 2019).

As a consequence of their abundance and ubiquity it is likely that synthetic microfibers are to become the next big issue to threaten water quality and wildlife, and there is growing concern about their potential danger to human health, to such an extent that the media are gradually beginning to call them "the new asbestos" (Tyree and Morrison 2017). However, if, on the one hand, the toxicity of asbestos fibers is mainly given by their physical properties, and particularly their sharpness and microscopic size which enables them to pierce cell wall membranes, interfere with DNA, and hence potentially lead to cancer (Ruosaari et al. 2008), the harmfulness of microfibers is principally attributed to chemical processes. In fact, microfibers can absorb persistent bioaccumulative and toxic (PBT) chemicals, which include persistent organic pollutants (POPs) and metals (Rios et al. 2007; Teuten et al. 2009; Pirc et al. 2016), hence enabling the uptake of toxic elements via consumption (Koelmans et al. 2016). Several studies have already reported the negative impact of microplastics on both freshwater invertebrates and fish, where ingestion of plastic microfibers was shown to cause physiological stress and signs of tumor formation (Eerkes-Medrano et al. 2015 and references therein). This has led to new concerns being raised about the possible health issues that may occur from human consumption of aquatic fauna and seafood (e.g. Sussarellu et al. 2016; Watts et al. 2015; Huerta Lwanga et al. 2016; Watts et al. 2016). In addition, a recent study (Liebmann et al. 2018) detected microplastic residues in human stool samples from eight different geographic regions (Austria, Finland, United Kingdom, Italy, Japan, the Netherlands, Poland and Russia), highlighting
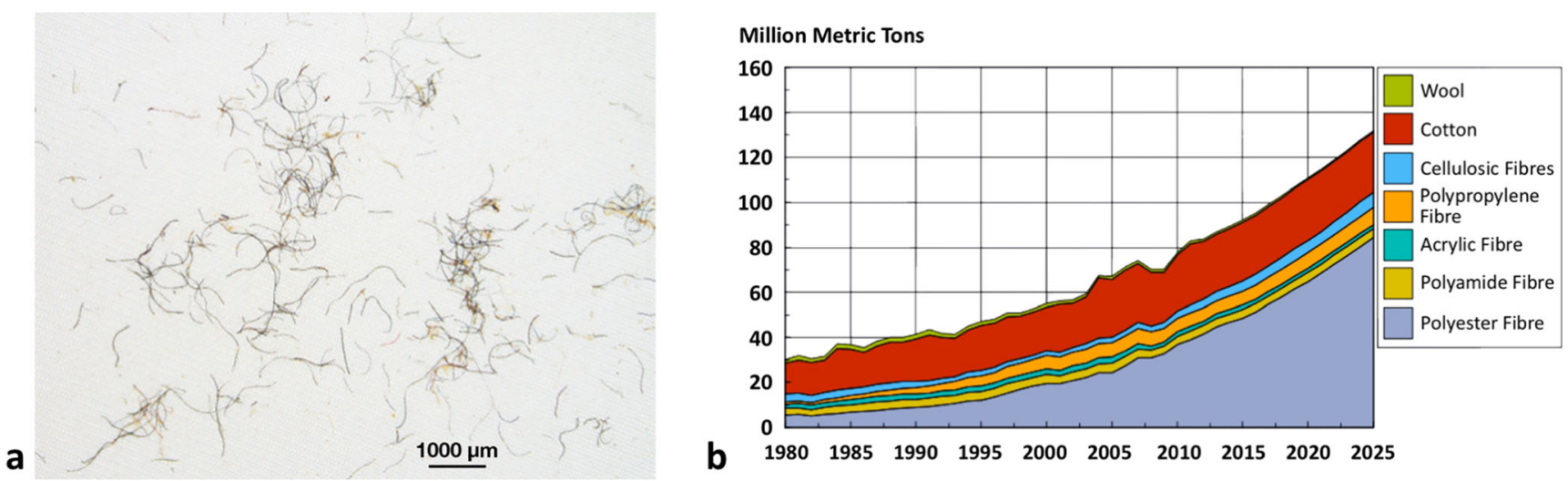

Fig. 2 a Fibers captured on a 20- $\mu$ m filter. Photo: Shreya Sonar, Bren School of Environmental Science and Management at UCSB, USA (Patagonia 2017); b Historical and projected fiber production (in million metric tons, Mt) from 1980 to 2025 (source Qin 2014) 
both the ubiquitous nature of the issue, and the potential impact of such an emerging contamination.

Despite the fact that to date no studies have shown that microfibers cause health problems in humans, and toxicological hazards associated with plastic microfibers ingestion are still not fully known (Galloway et al. 2016; Crawford and Quinn 2017), it is reasonable to assume that understanding the potential of microfibers as a vector for the introduction of contaminants in human bodies is only a question of time and advances in scientific research.

\section{Microfibers in groundwater: invisible contaminants in the hidden component of the water cycle}

Groundwater is the world's most important source of available freshwater supplying more than 2 billion people with safe water for domestic, drinking, agricultural and industrial purposes in both developing and industrialized nations worldwide. In addition, in many rural areas, groundwater is often the main freshwater source for both domestic and agricultural uses (Re and Zuppi 2011), providing farmers and local households with, generally free, supplies in close proximity to the users, and commonly without the need for complex treatment (Morris et al. 2003). Approximately 38\% of global irrigated areas rely on groundwater resources (Siebert et al. 2013), which has led to a 10-fold increase of groundwater extraction for agricultural irrigation over the last 50 years (WWAP 2016). Undoubtedly one of the main consequences of this high aquifer dependency is that any contamination of these waters can have serious repercussions on the local population, both directly, when groundwater is used for drinking purposes, and indirectly, when used for irrigation. Even though the international hydrogeological community is quite active in promoting actions targeted toward the long-term protection of global aquifer systems (IAH 2017), the hidden nature of groundwater makes it difficult to study and manage, and hampers the implementation of sound science-based management practices, especially when emerging issues are at stake, which is the case with microplastics pollution. In fact, despite the growing number of investigations targeted at surface waters, at present, there is a limited knowledge on possible plastic microfibers' presence and transport in aquifer systems. In fact, only a few studies targeted their occurrence in groundwater (e.g. e.g. Bouwman et al. 2018; Mintenig et al. 2019; Panno et al. 2019), while the presence of microscopic plastic fibers in tap water coming from underground sources was revealed for the first time only recently (Tyree and Morrison 2017). As a result of this lack of knowledge, groundwater still does not appear in literature on microfibers, as evidenced by some of the most cited publications on the present state-of-the-art research on microfibers pollution (Fig. 3; Bruce et al. (2017), nor in the legislation dealing with plastic contamination reduction, as in the case of the European plastics strategy (European Commission 2017), currently being prepared to help countries improve recycling, cut marine litter, and remove potentially dangerous chemicals.

Indeed, if natural microfibers such as asbestos can be present and move through soil and groundwater (Willenbring 2016), it is reasonable to hypothesize that synthetic microfibers will not be much different and could also be transported to, and within, aquifer systems.

For example, synthetic microfibers can be introduced into soils in different ways, either via land-applied WWTPs' biosolids (Habib et al. 1998; Zubris and Richards 2005; Rillig
Fig. 3 Conceptual box model of microfibers distribution, displaying observed and theorized pathways of microfibers transfer in the environment and biome. Modified from Bruce et al. (2017) with the addition of the red rectangles highlighting the steps where microfibers could enter the aquifer systems and be transported along the groundwater flow

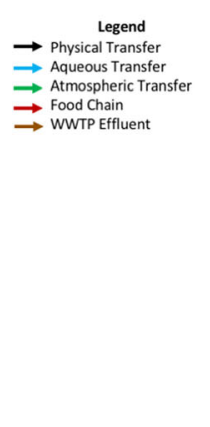








Fig. 4 Schematic representation of possible indirect pathways of microfiber transport in groundwater: a losing stream and $\mathbf{b}$ managed aquifer recharge (MAR, with treated water from WWTPs injected directly into the aquifer via an injection well). Blue arrows represent

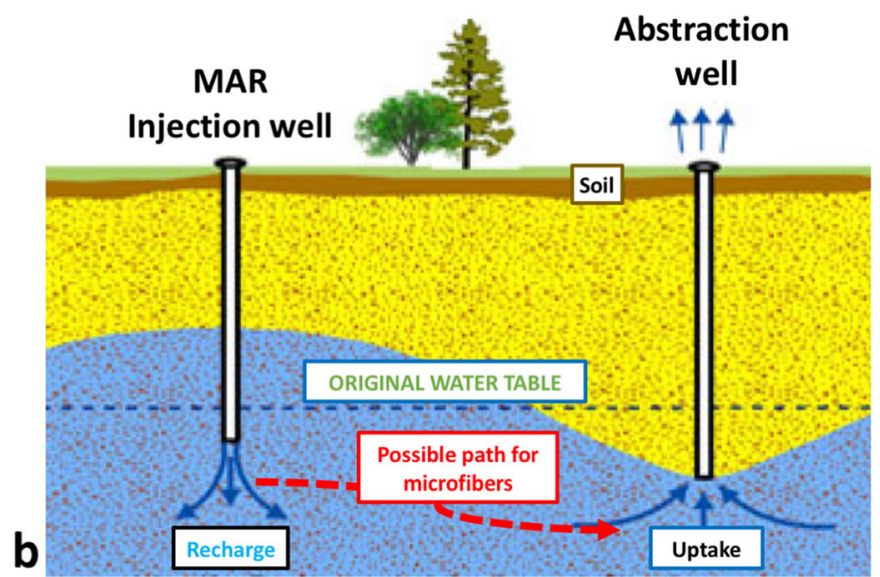

surface-water recharging groundwater; red arrows highlight the possible pathway for microfibers entering in to the supply well. (Modified from Government of Western Australia 2017)

than the possible intake of microplastics via the food chain (Fig. 5).

It seems therefore of great relevance to assess the occurrence of microfibers in aquifer systems, and to try to understand the possible harmful effects on human health due to plastic ingestion. To this end, a full understanding of transport dynamics and the assessment of how the morphology of the fibers can affect their movements along the flow paths are key issues that still need to be addressed.

The review of the known unknowns (i.e. items recognized by the scientific community as needing investigation) and the unknown unknowns (i.e. items not already present or still not adequately addresses in the scientific literature) of both synthetic and natural microfibers highlights the existing gaps in the field. It also highlights the challenges for the international community of hydrogeologists to go beyond the state of the art on contaminant hydrogeology (Table 1), thus supporting an effective and long-term protection of global groundwater resources.

\section{Challenges and opportunities}

The vulnerability of groundwater resources to anthropogenic pressure, associated with their crucial role in sustaining human activities and natural ecosystems, requires sound actions targeted at groundwater protection and management.

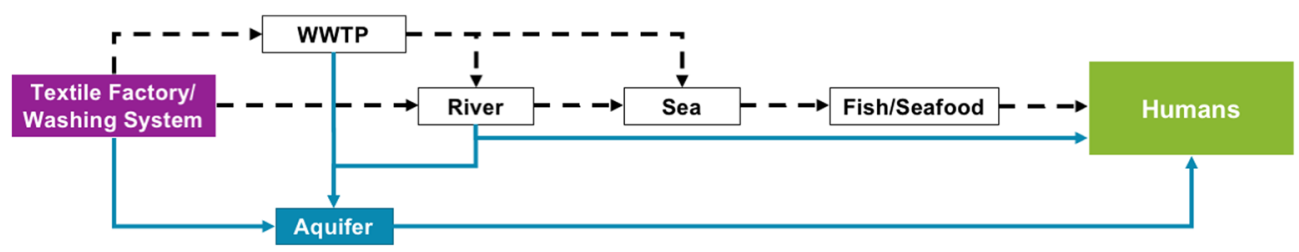

Fig. 5 Scheme of the potential mechanisms for plastic microfibers intake for humans. Dashed black line: food intake; blue line: drinking intake 
Therefore, pioneering investigations are required for an early identification of potential sources of contamination, before the problem is too widespread that only decontamination actions can be implemented.

The issue of synthetic microfiber pollution in groundwater is still far from being addressed, as the potential for aquifer contamination is only marginally mentioned in the recent literature on microplastic pollution. This means that in most cases, groundwater is only mentioned as a possible receptor of microfibers due to leaching and/or transfer in the biopores (e.g. Hohenblum et al. 2015; Huerta Lwanga et al. 2016, 2017; Rillig et al. 2017; Chae and An 2018; EerkesMedrano et al. 2018; He et al. 2018; Henry et al. 2019), while only a limited number of studies have attempted to assessed their presence in groundwater bodies (e.g. Bouwman et al. 2018; Mintenig et al. 2019).

It is under these premises, that the international hydrogeological community should address the following challenges:

1. Determine the occurrence of microfibers in groundwater and study their transport mechanisms along the flow paths. In particular, it will become fundamental to focus on the unknown processes associated to the fate and occurrence of microfibers in groundwater, thus contributing to the long-term protection of the natural environment and human health.

To this end, understanding transport mechanisms will be the first step towards demonstrating the potential impact that microfibers present in surface water can have on the underground system. Assessing microfibers' movement within different porous media would hence permit researchers to determine aquifer vulnerability to this emerging contaminant.

2. Assess the role of microplastics as carriers of contaminants within the aquifer. In particular, the analysis should focus on those classes of pollutants that have already been demonstrated to interact with microplastics (e.g. DDT, perfluoroalkylates, polycyclic aromatic hydrocarbons, polychlorinated biphenyl phthalates; Crawford and Quinn 2017), and potentially present in both industrial and agricultural sites.

3. Define a standardized procedure for microfibers sampling and monitoring in groundwater. This will represent a strong contribution to the research field since, at present, accurate detection and quantification techniques, including protocols for measurements and analyses, are still missing (Avio et al. 2016). Indeed, the creation of a standardized methodology in the development stage of this new research field would optimize any future research efforts, avoiding the biases due to methodological discrepancies, the lack of uniformity in the information, and associated issues in results comparisons. This would 
not only facilitate the replicability of any research and experiment, but also the communication to the civil society and policy makers, a fundamental requisite for the development of new regulations on microfibers contamination reduction. A homogenization of sampling procedures and analytical techniques, thus resulting from multidisciplinary collaboration with surface hydrologists, biologists and ocean scientists, that are already performing microfibers analyses in surface-water samples using spectroscopic analysis-e.g. Fourier Transform Infrared Spectroscopy (FTIR) or Raman spectroscopy (e.g. Habib et al. 1998; Liebezeit and Liebezeit 2014; Löder et al. 2015; Wiesheu et al. 2016; Hartline et al. 2016) will be necessary.

Addressing these challenges will therefore enable sound pollution assessments at the catchment scale, and will favor the inclusion of the hidden component of the water cycle starting at the earliest stages of this new branch of contaminant hydrology.

Acknowledgements The author would like to thank Prof. Elisa Sacchi (University of Pavia, Italy) for the critical review of the manuscript and Ms. Jo Oddie for the English review. The open access publication of this manuscript was supported by the InRoad funding scheme of the University of Pavia, Italy.

Open Access This article is distributed under the terms of the Creative Commons Attribution 4.0 International License (http:// creativecommons.org/licenses/by/4.0/), which permits unrestricted use, distribution, and reproduction in any medium, provided you give appropriate credit to the original author(s) and the source, provide a link to the Creative Commons license, and indicate if changes were made.

\section{References}

Aizenshtein EM (2015) Global and Russian output of polyester fibres in 2013. Fibre Chem 47:1-7

Arthur C, Baker J, Bamford H (2008) Proceedings of the international research workshop on the occurrence, effects and fate of microplastic marine debris. NOAA Technical Memorandum NOSOR\&R-30, NOAA, Silver Spring, MD, 49 pp

Avio CG, Gorbi S, Regoli F (2016) Plastics and microplastics in the oceans: from emerging pollutants to emerged threat. Mar Environ Res 128:2-11

Barnes DKA, Galgani F, Thompson RC, Barlaz M (2009) Accumulation and fragmentation of plastic debris in global environments. Philos Trans R Soc B 364:1985-1998

Barrows PW, Cathey SE, Petersen CW (2018) Marine environment microfiber contamination: global patterns and the diversity of microparticle origins. Environ Pollut 237:275-284

Boulanger G, Andujar P, Pairon JC, Billon-Galland MA, Dion C, Dumortier P, Brochard P, Sobaszek A, Bartsch P, Paris C, Jaurand MC (2014) Quantification of short and long asbestos fibers to assess asbestos exposure: a review of fiber size toxicity. Environ Health 13:59

Bouwman H, Minnaar K, Bezuidenhout C, Verster C (2018) Microplastics in freshwater environments. WRC report 2610/1/18,
Water Resources Commission. http://www.wrc.org.za/. Accessed Dec 2018

Browne MA, Crump P, Niven SJ, Teuten E, Tonkin A, Galloway T, Thompson R (2011) Accumulation of microplastic on shorelines worldwide: sources and sinks. Environ Sci Technol 45:9175-9179

Bruce NJ, Hartline N, Karba SN, Ruff B, Sonar S (2017) Microfiber pollution and the apparel industry. http://brenmicroplastics.weebly. com/uploads/5/1/7/0/51702815/bren-patagonia final report.pdf. Accessed Aug 2017

Carpenter EJ, Smith KL (1972) Plastics on the Sargasso Sea surface. Science 175:1240-1241

Chae Y, An Y-C (2018) Current research trends on plastic pollution and ecological impacts on the soil ecosystem: a review. Environ Pollut 240:387-395

Costa MF, Ivar do Sul JA, Silva-Cavalcanti JS, Araújo MCB, Spengler A, Tourinho PS (2010) On the importance of size of plastic fragments and pellets on the strandline: a snapshot of a Brazilian beach. Environ Monit Assess 168:299-304

Crawford CB, Quinn B (2017) Microplastic pollutants. Elsevier, Amsterdam, $336 \mathrm{pp}$

Di Ciaula A, Gennaro V (2016) Possible health risks from asbestos in drinking water. Epidemiol Prev 40:472-475

Eerkes-Medrano D, Thompson RC, Aldridge DC (2015) Microplastics in freshwater systems: a review of the emerging threats, identification of knowledge gaps and prioritisation of research needs. Water Res 75:63-82

Eerkes-Medrano D, Leslie HA, Quinn B (2018) Microplastics in drinking water: a review and assessment of an emerging concern. Curr Opin Environ Sci Health 7. https://doi.org/10.1016/j.coesh.2018.12.001

European Commission (2017) Strategy on plastics in a circular economy. http://ec.europa.eu/smart-regulation/roadmaps/docs/plan_2016 39 plastic_strategy_en.pdf. Accessed August 2017

Fendall LS, Sewell MA (2009) Contributing to marine pollution by washing your face: microplastics in facial cleansers. Mar Pollut Bull 58: $1225-1228$

Gago J, Carretero O, Filgueiras AV, Viñas L (2018) Synthetic microfibers in the marine environment: a review on their occurrence in seawater and sediments. Mar Pollut Bull 127:365-376

Galloway TS, Cole M, Lewis C (2016) Interactions of microplastic debris throughout the marine ecosystem. Nature Ecol Evolut 1:0116

Geissen G, Mol H, Klumpp E, Umlauf G, Nadal M, van der Ploeg M, van de Zeea SEATM, Ritsem CJ (2015) Emerging pollutants in the environment: a challenge for water resource management. Int Soil Water Conserv Res 3:57-65

Geyer R, Jambeck JR, Law KL (2017) Production, use, and fate of all plastics ever made. Sci Adv 3(7):e1700782

Government of Western Australia (2017) Managed aquifer recharge. http://www.water.wa.gov.au/urban-water/water-recyclingefficiencies/managed-aquifer-recharge. Accessed Sept 2017

Gregory M (1996) Plastic 'scrubbers' in hand cleansers: a further (and minor) source for marine pollution identified. Mar Pollut Bull 32(12):867-871

Gregory MR, Andrady AL (2003) Plastics in the marine environment. In: Andrady AL (ed) Plastics and the environment. Wiley, Hoboken, NJ

Habib D, Locke DC, Cannone LJ (1998) Synthetic fibers as indicators of municipal sewage sludge, sludge products, and sewage treatment plant effluents. Water Air Soil Pollut 103:1-8

Harper D (2017) Online etymology dictionary. http://www.etymonline. com/. Accessed Aug 2017

Hartline N, Bruce NJ, Karba SN, Ruff EO, Sonar SU, Holden PA (2016) Microfiber masses recovered from conventional machine washing of new or aged garments. Environ Sci Technol 50:11532-11538

He D, Luo Y, Lu S, Liu M, Song Y, Lei L (2018) Microplastics in soils: analytical methods, pollution characteristics and ecological risks. TrAC Trends Anal Chem 109:163-172 
Henry B, Laitala K, Kleppb IG (2019) Microfibres from apparel and home textiles: prospects for including microplastics in environmental sustainability assessment. Sci Total Environ 652:483-494

Hohenblum P, Liebmann B, Liedermann M (2015) Plastic and microplastic in the environment, vol 201. Environment Agency Austria, Umweltbundesamt, Vienna, 29 pp

Huerta Lwanga E, Gertsen H, Gooren H, Peters P, Salánki T, van der Ploeg M, Besseling E, Koelmans AA, Geissen V (2016) Microplastics in the terrestrial ecosystem: implications for Lumbricus terrestris (Oligochaeta, Lumbricidae). Environ Sci Technol 50:2685-2691

Huerta Lwanga E, Gertsen H, Gooren H, Peters P, Salánki T, van der Ploeg M, Besseling E, Koelmans AA, Geissen V (2017) Incorporation of microplastics from litter into burrows of Lumbricus terrestris. Environ Pollut 220:523-531

Hurley RR, Nizzetto L (2018) Fate and occurrence of micro(nano)plastics in soils: knowledge gaps and possible risks. Curr Opin Environ Sci Health 1:1-62

IAH (2017) The International Association of Hydrogeologists website. https://iah.org/. Accessed Aug 2017

International Agency for Research on Cancer (1977) Monographs on the evaluation of the carcinogenic risk of chemicals to man: asbestos, 14th edn. IARC, Lyon, France

Jawaid M, Khalil HPSA (2011) Cellulosic/synthetic fibre reinforced polymer hybrid composites: a review. Carbohydr Polym 86:1-18

Koelmans AA, Bakir A, Burton GA, Janssen CR (2016) Microplastic as a vector for chemicals in the aquatic environment. Environ Sci Technol 50:11532-11538

Koelmans AA, Nor NHM, Hermsen E, Kooi M, Miniteng SM, De France J (2019) Microplastics in freshwaters and drinking water: critical review and assessment of data quality. Water Res 155:410-422

Kosuth M, Mason SA, Wattenberg EV (2018) Anthropogenic contamination of tap water, beer, and sea salt. PLoS One 13(4):e0194970

Lemen RA, Dement JM, Wagoner JK (1980) Epidemiology of asbestosrelated diseases. Environ Health Perspect 34:1-11

Liebezeit G, Liebezeit E (2014) Synthetic particles as contaminants in German beers. Food Addit Contam 31:1574-1578

Liebmann B, Köppel S, Königshofer P, Bucsics T, Reiberger T, Schwab P (2018) Assessment of microplastic concentrations in human stool: preliminary results of a prospective study. Int. Conference on Emerging Contaminants (EMCON), 25-28 June 2018, Oslo, Norway

Löder MGJ, Kuczera M, Mintenig S, Lorenz C, Gerdts G (2015) Focal plane array detector-based micro-Fourier-transform infrared imaging for the analysis of microplastics in environmental samples. Environ Chem 12:563-581

Madl AK, Carosino C, Pinkerton KE (2010) Particle toxicities. In: Yost G (ed) Comprehensive toxicology, 2nd edn. Elsevier, New York

Magni S, Binelli A, Pittura L, Avio CG, Della Torre C, Parenti CC, Gorbi $\mathrm{S}$, Regoli F (2019) The fate of microplastics in an Italian wastewater treatment plant. Sci Total Environ 652:602-610

Mintenig SM, Int-Veena I, Löder MGJ, Primpke S, Gerdts G (2017) Identification of microplastic in effluents of waste water treatment plants using focal plane array-based micro-Fourier-transform infrared imaging. Water Res 108:365-372

Mintenig SM, Löder MGJ, Primpke S, Gerdts G (2019) Low numbers of microplastics detected in drinking water from ground water sources. Sci Total Environ 648:631-635

Miranda DD, de Carvalho-Souza GF (2016) Are we eating plasticingesting fish? Mar Pollut Bull 103:109-114

Morris BL, Lawrence ARL, Chilton PJC, Adams B, Calow RC, Klinck BA (2003) Groundwater and its susceptibility to degradation: a global assessment of the problem and options for management. Early warning and assessment report series, RS. 03-3. United Nations Environment Programme, Nairobi
Murphy F, Ewins C, Carbonnier F, Quinn B (2016) Wastewater treatment works (WwTW) as a source of microplastics in the aquatic environment. Environ Sci Technol 50:5800-5808

National Academies of Sciences, Engineering and Medicine (2016) Using graywater and Stormwater to enhance local water supplies: an assessment of risks, costs, and benefits. The National Academies Press, Washington, DC, $420 \mathrm{pp}$

Nor NH, Obbard JP (2014) Microplastics in Singapore's coastal mangrove ecosystems. Mar Pollut Bull 79:278-283

Panno SV, Kelly WR, Scott J, Zheng W, McNeish RE, Timothy NH, Hoellein J, Baranski EL (2019) Microplastic contamination in karst groundwater systems. Groundwater 57:189-196

Patagonia (2017) The cleanest line. https://www.patagonia.com/blog/ 2017/02/an-update-on-microfiber-pollution/. Accessed August 2017

Pirc U, Vidmar M, Mozer A, Kržan A (2016) Emissions of microplastic fibers from microfiber fleece during domestic washing. Environ Sci Pollut Res 23:22206-22211

Polissar L, Severson RK, Boatman ES (1983) Cancer risk from asbestos in drinking water: summary of a case-control study in western Washington. Environ Health Perspect 53:57-60

Qin Y (2014) Global fibres overview. Synthetic Fibres Raw Materials Committee Meeting at APIC, Pattaya City, Thailand, May 2014

Re V, Zuppi GM (2011) Influence of precipitation and deep saline groundwater on the hydrological systems of Mediterranean coastal plains: a general overview. Hydrol Sci J 56:966-980

Rillig MC (2012) Microplastic in terrestrial ecosystems and the soil? Environ Sci Technol 46:6453-6454

Rillig MC, Ingraffia R, de Souza Machado AA (2017) Microplastic incorporation into soil in agroecosystems. Front Plant Sci 8:1805

Rios LM, Moore C, Jones PR (2007) Persistent organic pollutants carried by synthetic polymers in the ocean environment. Mar Pollut Bull 54: $1230-1237$

Rochman CM, Tahir A, Williams SL, Baxa DV, Lam R, Miller JT, Teh FC, Werorilangi S, Swee J, Teh SJ (2015) Anthropogenic debris in seafood: plastic debris and fibers from textiles in fish and bivalves sold for human consumption. Sci Rep 5:14340

Ruosaari S, Hienonen-Kempas T, Puustinen A, Sarhadi VK, Hollmén J, Knuutila S, Saharinen J, Wikman H, Anttila S (2008) Pathways affected by asbestos exposure in normal and tumour tissue of lung cancer patients. BMC Med Genet 2008(1):55

Schymanski D, Goldbeck C, Humpf HU, Fürst P (2018) Analysis of microplastics in water by micro- Raman spectroscopy: release of plastic particles from different packaging into mineral water. Water Res 129:154-162

Siebert S, Henrich V, Frenken K, Burke J (2013) Update of the digital global map of irrigation areas (GMIA) to version 5. FAO, Rome

Strunz H (2001) Mineralogical tables: chemical-structural mineral classification system, 9th edn. Schweizerbart, Berlin, $870 \mathrm{pp}$

Sussarellu R, Suquet M, Thomas Y, Lambert C, Fabioux C, Pernet MEJ, Le Goïc N, Quillien V, Mingant C, Epelboin Y, Corporeau C, Guyomarch J, Robbens J, Paul-Pont I, Soudant P, Huvet A (2016) Oyster reproduction is affected by exposure to polystyrene microplastics. Proc Natl Acad Sci USA 113:2430-2435

Teuten EL, Saquing JM, Knappe DR, Barlaz MA, Jonsson S, Björn A, Rowland SJ, Thompson RC, Galloway TS, Yamashita R, Ochi D, Watanuki Y, Moore C, Viet PH, Tana TS, Prudente M, Boonyatumanond R, Zakaria MP, Akkhavong K, Ogata Y, Hirai H, Iwasa S, Mizukawa K, Hagino Y, Imamura A, Saha M, Takada $H$ (2009) Transport and release of chemicals from plastics to the environment and to wildlife. Philos Trans R Soc Lond B Biol Sci. 364:2027-2045

Thompson RC, Olsen Y, Mitchell RP, Davis A, Rowland SJ, John AWG, Mcgonigle D, Russell AE (2004) Lost at sea: where is all the plastic? Science 304:838 
Tweedale G, McCulloch J (2004) Chrysophiles versus chrysophobes: the white asbestos controversy, 1950s-2004. Isis 95:239-259

Tyree C, Morrison D (2017) INVISIBLES: the plastic inside us. https:// orbmedia.org/stories/Invisibles_plastics/multimedia. Accessed September 2017

Tyree C, Morrison D (2018) Plus plastic: microplastics found in global bottled water. https://orbmedia.org/stories/plus-plastic/text. Accessed December 2018

UNEP and GRID-Arendal (2016) Marine litter vital graphics. United Nations Environment Programme, Nairobi

Van Cauwenberghe L, Vanreusel A, Mees J, Janssen CR (2013) Microplastic pollution in deep-sea sediments. Environ Pollut 182: 495-499

Watts AJR, Urbina MA, Corr S, Lewis C, Galloway TS (2015) Ingestion of plastic microfibers by the crab Carcinus maenas and its effect on food consumption and energy balance. Environ Sci Technol 49: $14597-14604$

Watts AJR, Urbina MA, Goodhead R, Moger J, Lewis C, Galloway TS (2016) Effect of microplastic on the gills of the shore crab Carcinus maenas. Environ Sci Technol 50:5364-5369

WHO (1986) Asbestos and other natural mineral fibres. Environmental Health Criteria, WHO, Geneva, 35 pp
WHO (2000) Air quality guidelines for Europe, second edn. European series no. 91, WHO, Geneva, 288 pp

WHO (2013) Asbestos in drinking-water background document for development of WHO guidelines for drinking-water quality. In: Guidelines for drinking-water quality, vol 2, 2nd edn. WHO, Geneva

Wiesheu AC, Anger PM, Baumann T, Niessner R, Ivleva NP (2016) Raman microspectroscopic analysis of fibers in beverages. Anal Methods 8(28):5722-5725

Willenbring J (2016) The fate of Asbestos in soil: remediation prospects and paradigms. In: Proceedings of the 2016 American Chemical Society meeting, Philadelphia, PA, Aug. 22, 2016. https:// semspub.epa.gov/work/01/593287.pdf. Accessed August 2017

WWAP (2016) The United Nations world water development report 2016: water and jobs. UNESCO, Paris

Yang D, Shi H, Li L, Li J, Jabeen K, Kolandhasamy P (2015) Microplastic pollution in table salts from China. Environ Sci Technol 49:13622-13627

Zubris KAV, Richards BK (2005) Synthetic fibers as an indicator of land application of sludge. Environ Pollut 138:201-211 